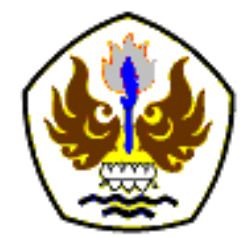

INFOMATEK

Volume 20 Nomor 1 Juni 2018

\title{
UPAYA PERLINDUNGAN SUMBER DAYA AIR MELALUI PENGELOLAAN SAMPAH TERINTEGRASI BERBASIS ECOPRENEUR DI DAS CIKAPUNDUNG
}

\author{
Mohamad Satori ${ }^{*}$ \\ Program Studi Teknik Industri \\ Fakultas Teknik- Universitas Islam Bandung
}

\begin{abstract}
Abstrak: Sungai Cikapundung tidak bisa dipisahkan dari masyarakat Kota Bandung, selain karena sangat berarti bagi kehidupan warga Bandung dan sekitarnya juga sungai tersebut memiliki fungsi hidrologis bagi Cekungan Bandung. Namun sayangnya Sungai Cikapundung juga telah menjadi tempat pembuangan berbagai limbah warga Kota Bandung sehingga kualitas air sungai menurun. Salah satu penyebab tercemarnya Sungai Cikapundung adalah pembuangan limbah padat atau sampah rumah tangga. Hal ini disebabkan karena manajemen pengelolaan sampah di DAS Cikapundung kurang baik, baik dari segi infrastruktur maupun manajemen. Pengelolaan sampah terpadu berbasis masyarakat melalui penguatan ecopreneur ini merupakan alternatif yang ditawarkan untuk model pengelolaan sampah di DAS Cikapundung. Konsep tersebut memadukan tiga komponen penting dalam pembangunan berkelanjutan yakni lingkungan, ekonomi dan sosial.
\end{abstract}

Kata kunci: ecopreneur, sampah, Sungai Cikapundung

\section{PENDAHULUAN}

Sungai memiliki peranan yang sangat penting dan strategis bagi seluruh kehidupan terutama manusia. Sungai juga merupakan sumber kehidupan bagi manusia, oleh karenanya keberadaan sungai tidak bisa dipisahkan dari kehidupan manusia. Peran sungai dalam sebuah kemunitas masyarakat termasuk perkotaan menjadi sangat penting terutama dalam upaya mempertahankan sumber daya

*)mohamad_satori@yahoo.com

Pertama diterima : 15 Januari 2018

Direvisi : 2 Februari 2018

Disetujui untuk publikasi: 8 Februari 2018. air secara berkelanjutan. Pengelolaan Daerah Aliran Sungai (DAS) merupakan salah satu aspek dari Pengelolaan Sumber Daya Air (PSDA) pada suatu Wilayah Pengembangan Sumber Air (WPSA) yang merupakan upaya pendayagunaan sumber air secara terpadu dengan upaya pengendalian dan pelestariannya (Suganda, at.al., 2009 [1]). Pasal 1 PP No. 37 tahun 2012 menyebutkan bahwa DAS adalah suatu wilayah daratan yang merupakan satu kesatuan dengan sungai dan anak-anak sungainya, yang berfungsi menampung, menyimpan dan 
mengalirkan air yang berasal dari curah hujan ke danau atau ke laut secara alami, yang batas di darat merupakan pemisah topografis dan batas di laut sampai dengan daerah perairan yang masih terpengaruh aktivitas daratan. Pengelolaan DAS tidak terlepas dari berbagai permasalahan, antara lain masalah penurunan sumber daya alamiah, polusi dari berbagai sumber, serta konflik penggunaan lahan di sekitar DAS (Clark, 1996 [2]).

Sungai Cikapundung merupakan salah satu sungai sangat strategis tidak saja di Kota Bandung akan tetapi di Jawa Barat (Yustiani dkk., 2016 [3]) Sungai Cikapundung telah menjadi ikon baik bagi Kota Bandung maupun Jawa Barat. Secara fisik Sungai Cikapundung, memiliki panjang 28 kilometer, melintasi 11 kecamatan di tiga kabupaten kota, yaitu Kota Bandung, Kabupaten Bandung dan Kabupaten Bandung Barat. Daerah hulu Sungai Cikapundung terletak di daerah Cigulung dan Cikapundung, Maribaya, (Kab. Bandung Barat). Sedangkan bagian tengah termasuk Cikapundung Gandok dan Cikapundung Pasir Luyu (Kota Bandung). Sungai Cikapundung bermuara di Sungai Citarum di Bale Endah (Kab. Bandung) dan menjadi salah satu dari 13 anak sungai utama yang memasok air untuk Sungai Citarum. Sungai Cikapundung memiliki luas daerah tangkapan di bagian hulu sebesar 111,3 km², di bagian tengah seluas $90,4 \mathrm{~km}^{2}$ dan di bagian hilir seluas $76,5 \quad \mathrm{Km}^{2}$. Jumlah penduduk yang berdomisili di DAS Cikapundung mencapai 750.559 jiwa. Sedangkan jumlah penduduk tertinggi berada di Kelurahan Tamansari 28.729 jiwa (BPLH Kota Bandung dalam http://www.citarum.org, diakses Januari 2018 [4]).

Fungsi Sungai Cikapundung bagi masyarakat Kota bandung dan sekitarnya antara lain: (1) drainase utama pusat kota; (2) penggelontor kotoran dan pembuangan limbah domestik maupun industri sampah kota; (3) objek wisata Bandung (Maribaya, Curug Dago, kebun binatang dII); (4) penyedia air baku Perusahaan Daerah Air Minum (PDAM) Kota Bandung yang membangun instalasi penyadapan di Dago Pakar, Dago, dan di Badak Singa; (5) pemanfaatan energi yang dikelola oleh PT Indonesia Power-Unit Saguling yang mendirikan instalansi di PLTA Bengkok dan PLTA Dago Pojok, serta (6) sebagai sarana irigasi pertanian. Kini Sungai Cikapundung menunjukkan kondisi yang makin memprihatinkan baik dari segi kualitas maupun kualitas. Secara alamiah, sungai mampu memulihkan diri dalam proses self purification (Yustiani dkk., 2017 [5]). Namun hasil uji kualitas air di beberapa titik menunjukkan bahwa air di Sungai Cikapundung telah tercemar berat, serta kuantitas air juga makin menurun terutama musim kemarau. Hal ini terjadi seiring dengan 
pertumbuhan penduduk dan tumbuh kembangnya berbagai aktifitas di bantaran Sungai Cikapundung tersebut.

Salah satu parameter penting berkaitan kualitas air sungai misalnya BOD (biochemical oxygen demand), jauh melampaui ambang batas dan meningkat dari tahun ke tahun baik di daerah hulu maupun daerah hilir (Gambar 1). Pencemaran BOD meningkat signifikan mulai tahun 2005, dimana pada saat ini terjadi musibah longsornya TPA Leuwigajah sehingga sampah menumpuk di berbagai sudut Kota bandung dan Bandung dinyatakan sebagai darurat sampah. Kandungan organik air sungai Cikapundung sangat melebihi nilai yang disyaratkan oleh Peraturan Menteri Kesehatan Nomor 492/Menkes/Per/IV/2010 yaitu $10 \mathrm{ppm}\left(\mathrm{KmnO}_{4}\right)$ atau ekivalen dengan 2 ppm TOC. Dibutuhkan penurunan sekitar 18 ppm TOC dari air baku untuk memenuhi peraturan tersebut (Waspola-Gemricik, 2013 [6]).

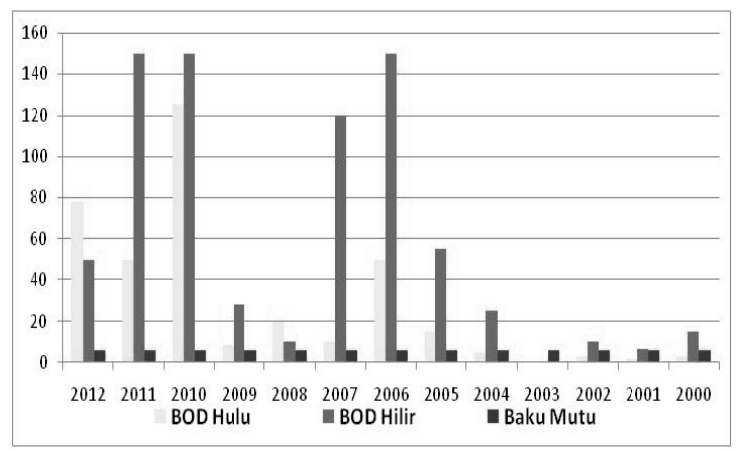

Gambar 1

Grafik Time Series kandungan BOD Sungai Cikapundung

\section{MASALAH UMUM}

Secara umum bahwa permasalah sungai Cikapundung terdiri masalah kualitas air dan masalah debitasi atau kuantitas air. Masalah kualitas air dapat dilihat dari uji laboratorium untuk berbagai parameter yang menunjukkan jauh di atas baku mutu lingkungan. Sementara itu dari segi kuantitas air pada musim hujan sangat melimpah sedangkan pada musim kemarau kekurangan air dan menjadi masalah karena sungai Cikapundung sebagai sumber air baku PDAM Tirtawening Kota Bandung.

Manajemen sanitasi merupakan inti permasalahan dari sungai Cikapundung, mulai dari penanganan limbah ternak yang ada di bagian hulu sungai (daerah Lembang), kemudian masalah pembuangan limbah rumah tangga baik limbah cair maupun limbah padat (sampah) di sepanjang aliran sungai Cikapundung. Populasi ternak yang ada di wilayah Lembang antara lain meliputi : ternak sapi perah dan potong sebanyak 13.318 ekor, ternak ayam 48.840 ekor, ternak kambing sebanyak 5.415 ekor (Dinas Peternakan dalam BPLHD Jabar, 2011). Para peternak tersebut terutama ternak sapi membuang limbahnya ke sungai Cikapundung. Selain limbah peternakan juga limbah manusia baik limbah cair maupunlimbah padat (sampah). Berdasarkan hasil base line survey yang diselenggarakan Gemricik bekerja sama 
dengan Waspola Facilities (2013) diperoleh gambaran bahwa pada umumnya pemukiman yang ada di DAS Cikapundung tidak memiliki infrastruktur sanitasi yang memadai sehingga limbah tersebut masuk ke sungai Cikapundung.

Masalah sosial juga merupakan masalah yang rumit di DAS Cikapundung, mulai dari masalah persepsi masyarakat terhadap sungai, hingga yang berhubungan dengan perilaku membuang limbah ke sungai. Walaupun hal ini berkaitan dengan infrastruktur sanitasi akan tetapi secara personal masih banyak masyarakat yang menganggap bahwa sungai Cikapundung sebagai tempat pembuangan. Hal tersebut ditandai dengan adanya kebiasaan masyarakat yang membuang sampah ke sungai dan buang air besar (BAB) ke sungai Dari penelitian yang dilakukan ketika ditanya alasan masyarakat buang limbah ke sungai Cikapundung mayoritas menjawab karena kebiasaan (74\%) [6]. Disamping itu bila diamati hampir setiap rumah mengalirkan limbah rumah tangganya, baik dari WC maupun dari kamar mandi, dengan menggunakan "lodong" ke sungai tanpa melalui pengolahan terlebih dahulu.

Masalah tata pemukiman yang makin padat dan tidak beraturan menambah rumitnya masalah sanitasi di DAS Cikapundung. Umumnya pemukiman di di DAS Cikapundung, terutama di sekitar Tamansari, berhubungan langsung dengan badan sungai. Sungai

Cikapundung di kanan kirinya "dikepung" oleh bangunan. Sebagian besar bangunan yang merupakan permukiman berada langsung di bantaran sungai.Data BPLH Kota Bandung menyebutkan ada sekitar 1,058 rumah yang berada dekat dengan bantaran Sungai Cikapundung.Hampir seluruhnya membuang limbah langsung ke sungai. Karenanya sungai Cikapundung ini menerima limbah lebih dari 2,5 juta liter setiap harinya, yang sebagian besar berasal dari limbah rumah tangga [4]. Padahal berdasarkan Peraturan Pemerintah No. 38 tahun 2011 bahwa sungai harus memiliki sepadan. Di sepanjang kiri dan kanan badan sungai. Sebagaimana Pasal 9 Peraturan Pemerintah No. 38 tahun 2011 disebutkan bahwa syarat sepadan sungai adalah paling sedikit berjarak $10 \mathrm{~m}$ (sepuluh meter) dari tepi kiri dan kanan palung sungai sepanjang alur sungai, dalam hal kedalaman sungai kurang dari atau sama dengan $3 \mathrm{~m}$ (tiga meter). Gambar 2 memperlihatkan kondisi permukiman di bantaran Sungai Cikapundung.

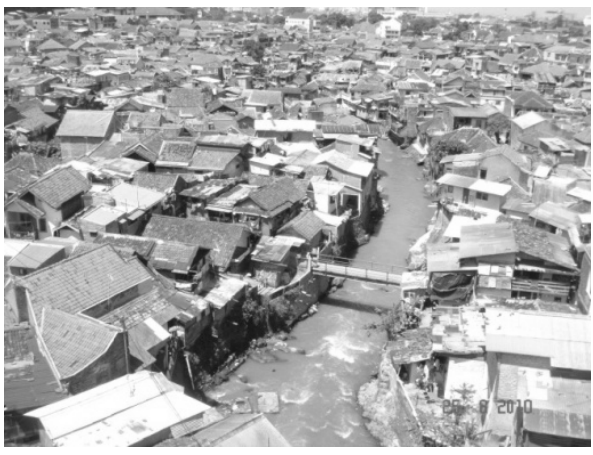

Gambar 2.

Kondisi Pemukiman di DAS Cikapundung 


\section{STATE OF THE ART}

Manajemen pengelolaan sampah di berbagai negara kini telah mengalami pergeseran dari pendekatan ujung pipa (end of pipe treatmen) ke pendekatan pencegahan (reducing), penggunaan ulang (reusing) dan pendaurulangan (recycling) atau yang dikenal dengan 3R. Hal ini disebabkan karena laju timbulan sampah yang makin meningkat sementara daya tampung alam dan daya dukung alam yang makin terbatas terutama di daerah perkotaan. Rendahnya tingkat pelayanan serta berbagai kasus yang mencuat belakangan ini terkait dengan keberadaan TPA (Tempat Pemrosesan Akhir), baik menyangkut kapasitas maupun menyangkut dampak lingkungan yang terjadi, menunjukan makin timpahnya daya dukung alam terhadap laju timbulan sampah terutama daerah perkotaan.

Melihat permasalahan persampahan yang makin kompleks maka di berbagai negara kini telah mengembangkan manajemen pengelolaan sampah terpadu (integrated solid waste management/ ISWM). Hal ini disebabkan karena tidak ada teknologi tunggal yang dapat menyelesaikan persoalan persampahan (Tehrani et al., 2009 dalam Zaman A.U., 2010 [7]). Sebagaimana halnya konsep pembangunan berkelanjutan yang mengintegrasikan antara faktor lingkungan, sosial dan ekonomi maka dalam pengelolaan sampah berkelanjutan juga perlu mengintegrasikan ketiga hal tersebut dalam manajemen pengelolaan sampah kota. Pengelolaan sampah terintegrasi umumnya merupakan metode pengelolaan sampah yang digunakan di berbagai negara terutama negara-negara berkembang. Pengelolaan sampah yang terintegrasi menyediakan pililihan pengolahan sampah secara fleksibel untuk jenis sampah yang berbeda seperti plastik, gelas, sampah organik atau sampah yang dapat dikomposkan [7]. Pengelolaan sampah terpadu merupakan pilihan yang dianggap tepat saat ini dengan teknik dan manajemen yang disesuaikan untuk mencapai tujuan dari pengelolaan sampah itu sendiri (Tchobanoglous, 2002 [8]).

Konsep keterpaduan dalam pengelolaan sampah dapat dilihat dari berbagai aspek, mulai dari aspek metode, teknologi, aspek ekonomi, hingga aspek pelakunya. Berdasarkan aspek metode, pengelolaan sampah terintegrasi dimulai dari penerapan konsep pencegahan (reduction), penggunaan ulang (reusing), pendaur-ulangan (recycling and composting), insenerasi, hingga penimbunan (landfilling) (Joe E. H. dkk, http://ohioline.osu.edu, diakses April 2014 [9]). Dari aspek teknik dan teknologi pengelolaan sampah terintegrasi dapat memadukan berbagai teknik pendaurulangan. Definisi 
terintegrasi juga dapat diartikan sebagai sebuah pertalian (connection) dan adaptasi dari suatu teknologi proses dasar yang digunakan yang kemudian menghasilkan kegiatan yang terintegrasi dan menghasilkan sebuah teknologi yang kompleks dan bekerja sama satu dengan lainnya secara lebih efektif (Nowosielski, at.al, 2008 [10]).

Pengelolaan sampah terpadu dengan melibatkan semua stakeholders yang terlibat dalam pengelolaan sampah kota adalah sebagaimana dikemukakan Guerrero (2013 [11]) yang dihimpun dari brerbagai literatur dan hasil studi, mengemukakan bahwa faktorfaktor yang berpengaruh terbagi dalam dua kelompok yaitu: (a) faktor yang mempengaruhi elemen individual, dan (b) faktor yg mempengaruhi sistem keseluruhan. Hal ini menunjukkan bahwa dalam pengelolaan sampah banyak pihak yang harus terlibat bukan hanya tanggung jawab pemerintah kota saja. Walaupun begitu apa yang dikemukakan oleh Guerrero tersebut masih bersifat normatif dan belum ada gambaran yang jelas tentang sistem manajemen pengelolaan sampah terintegrasi yang optimal [11].

Pemilihan modal ISWM yang lebih komrehensif seperti dikemukakan Surjandari (2009 [12]) dimana proses pengolahan sampah meliputi empat aspek (sosial, ekonomi, lingkungan dan teknologi) dengan masing-masing aspek terdiri dari empat alternatif (recycle, kompos, landfill dan incenerator) seperti terlihat pada Gambar 4. Berdasarkan penelitian yang dilakukan di Jakarta dengan menggunakan metode AHP (Analytic Hirarchy Process) untuk menentukan skala prioritas pengolahan sampah menurut masyarakat dan hasil pembobotan dengan menggunakan bantuan perangkat lunak expert choice, memperlihatkan bahwa aspek sosial mempunyai preferensi yang paling tinggi $(53,8 \%)$, diikuti dengan aspek lingkungan (26\%), ekonomi $(14,3 \%)$ dan teknologi $(5,9 \%)$ [12]. Sedangkan skala prioritas alternatif pengolahan sampah yang tertinggi adalah pengomposan (42,5\%), recycle $(30,2 \%)$, incenerator $(21,5 \%)$ dan landfill $(5,8 \%)$. Dari aspek finansial Surjandari mengemukakan bahwa pengolahan sampah (organik) dengan metode pengomposan merupakan cara yang paling cost effecitive bila dibanding alternatif lainnya yaitu daur ulang (untuk sampah anorganik) dan waste to energy. Akan tetapi untuk mencapai Break Even Point (BEP) dari pembuatan kompos dapat dicapai jika penjualannya mencapai 711 ton. Sedangkan dilihat dari sudut Benefit-Cost ratio $(B / C)$ yang merupakan perbandingan hasil penjualan dengan biaya operasi adalah sebesar $1,41 \%$, artinya dengan biaya operasi Rp 355.500 akan mendapatkan keuntungan 1,41 kalinya. Hal ini menunjukkan bahwa pengomposan sangat layak dilaksanakan. 
Sedangkan ditinjau dari Return of Invesment (ROI) yang merupakan ukuran perbandingan antara keuntungan dengan biaya operasi, didapatkan nilai $\mathrm{ROI}$ sebesar 0,406 , artinya untuk setiap Rp 100 yang dikeluarkan akan didapatkan keuntungan $\mathrm{Rp} 0,406$. Jika diasumsikan 55\% atau 330 ton(55\% x 6000 ton) sampah penduduk DKI Jakarta dijadikan kompos, maka akan didapat keuntungan sebesar Rp 867.000 dalam sehari. Pemda DKI Jakarta bukan hanya dapat mereduksi timbunan sampah tetapi dapat menambah Pendapatan Asli Daerah (PAD).

Pengelolaan sampah secara terintegrasi seperti apapun modelnya yang paling penting apakah model tersebut cost effective tidak. Oleh karena itu aspek ekonomi atau finansial dalam ISWM sangat penting untuk mempertimbangkan model pengintegrasian seperti apa yang paling optimal. Untuk mempertimbangkan aspek ekonomi dalam ISWM Prawiradinata (2004 [13]) mengembangkan ISWM di Ohio City yang merupakan pengembangan dari Chang's Model (1996 [14]). Bila dalam Cang's model penekanannya pada TPA sanitary landfill maka ISWM yang dikembangkan Prawiradinata diperluas dalam hal : (i) fasilitas pengomposan, (ii) penutupan TPA dan biaya penggantiannya, (iii) operasional TPA secara serentak dan simultan, (iv) skala ekonomi di TPA dan operasional kompos dan ekspansi kapasitas, (v) kapasitas seumur hidup - kapasitas $\begin{array}{llll}\text { kumulatif-TPA, (vi) } & \text { promosi } & \text { program } \\ \text { pengalihan masalah } & \text { sampah } & \text { kepada } \\ \text { konsumen, dan (vii) } & \text { berbagai } & \text { metode }\end{array}$ pengumpulan pada sumber dengan berbagai skala pengumpulan. Dari hasil penelitian Prawiradinata tersebut diperoleh bahwa metode pengelolaan sampah dengan menggunakan landfilling system (TPA) bukan satu-satunya metode yang dapat dikembangkan dan untuk memperpanjang umur TPA tersebut perlu diintegrasikan dengan sistem daur ulang. Dengan menggunakan model integer programing diperoleh bahwa mengintegrasikan sistem daur ulang dalam sistem pengelolaan sampah dengan alternatif model sebagaimana diperlihatkan dalam gambar, adalah merupakan solusi optimal dalam pengelolaan sampah kota [14].

Konsep pengelolaan sampah terpadu harus dimulai dari bagaimana pemilihan teknik daur ulang yang dapat mengurangi tingkat pencemaran di satu sisi dan biaya yang dapat diterima di sisi lain [10]. Metode pemilihan teknologi tersebut disebut Best Available Techniques (BAT). Metode ini digunakan Komisi Eropa sebagai referensi untuk pemilihan teknologi daur ulang dengan dampak lingkungan minimal dan biaya yang dapat diterima. Berdasarkan metode tersebut kemudian diusulkan model teknik daur ulang ulang terintegrasi seperti Gambar 3 di bawah ini. 


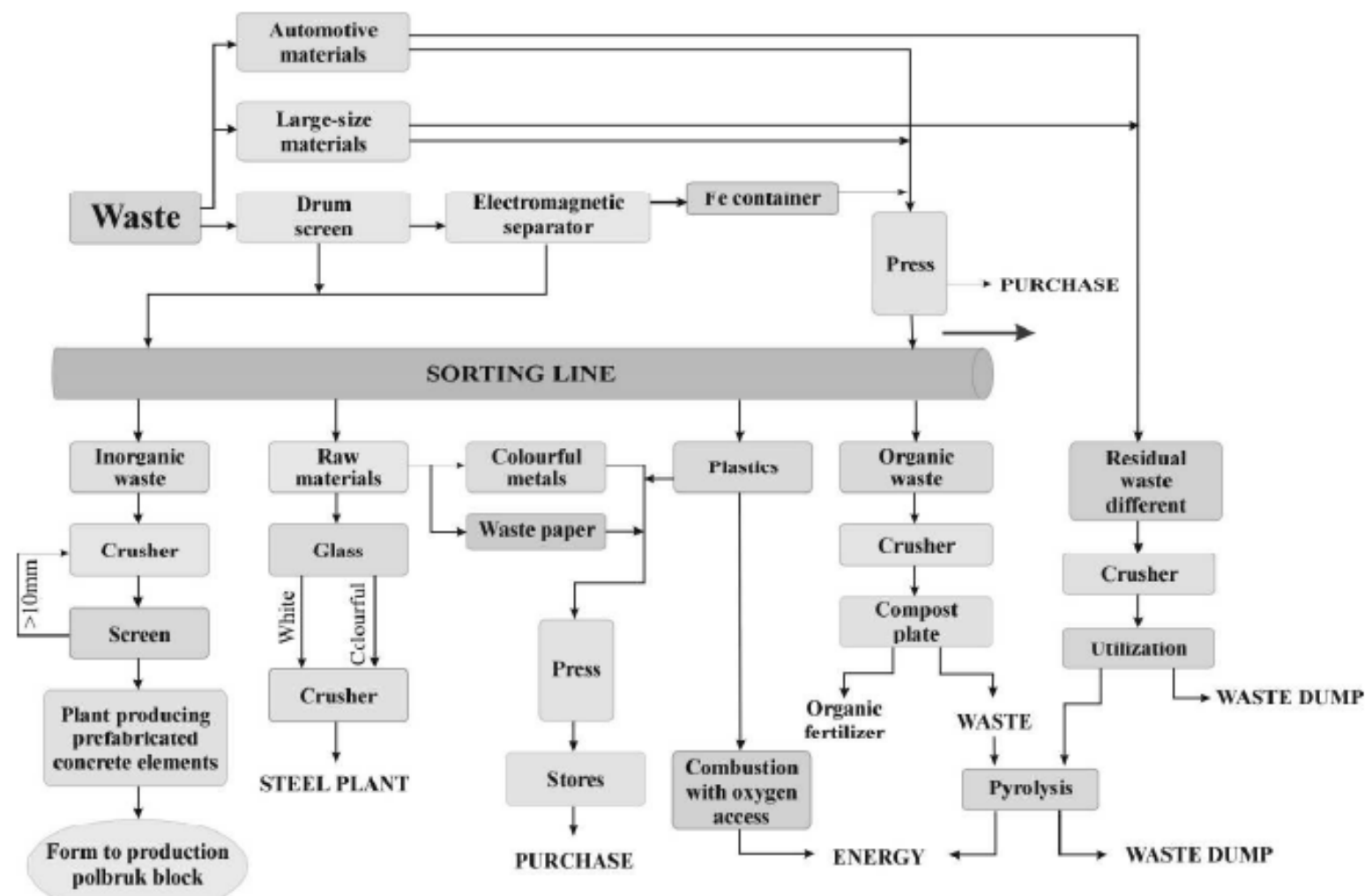

Gambar 3.

BAT Pengelolaan Sampah Terpadu [10]

\section{GAGASAN PENGELOLAAN SAMPAH TERPADU BERBASIS ECOPERENEUR DI DAS CIKAPUNDUNG}

Seiring dengan tuntutan dunia internasional sebagaimana tertuang dalam Agenda 21 bahwa konsep pembangunan yang dilakukan oleh suatu daerah harus menggunakan konsep pembangunan berkelanjutan. Hal yang sama juga untuk pengelolaan DAS Cikapundung yang tentunya di dalamnya termasuk masalah persampahan. Untuk mencapai pembangunan berkelanjutan di perkotaan antara lainharus memenuhi tiga pilar yaitu aspek lingkungan,ekonomi dan sosial (Salim, 1993 [15]). Dalam mengintegrasikan ketiganya maka diperlukan strategi perancangan kota yang memperhatikan aspek-aspek lingkungansosial-ekonomi secara seimbang-dinamis, memperhatikan pembangunan spesifik lokal, serta bersifat tidak linear melainkan mengandung prosesumpan balik (Becker, 1997 [16]).

\section{a. Treatment di sumber sampah}


Pemilahan sampah di sumber sampah merupakan langkah awal yang sangat penting dalam ISWM karena sampah akan diperlakukan secara berbeda sesuai dengan jenis dan karakteristiknya, Taiwo, (2009 [17]) mengemukakan bahwa pemilahan sampah juga merupakan salah bentuk partisipasi masyarakat yang sangat penting dalam ISWM. Hal ini juga sesuai dengan UU No. 18 tahun 2008 bahwa masyarakat diwajibkan memilah sampah. Pemilahan minimal menjadi dua jenis, yaitu sampah basah/ sampah mudah busuk/ sampah organik, dan sampah kering/ sampah tidak mudah busuk/ sampah anorganik. Untuk beberapa sumber sampah, perlu dipisahkan juga sampah jenis B3 (bahan berbahaya dan beracun) seperti baterai bekas, jarum suntik, pampers, dan lain-lain. Pemilahan sampah harus dijadikan sebagai gerakan perubahan budaya dan dilakukan dengan menggunakan sarana yang mudah dan sederhana.
Setelah dipilah, bagi masyarakat yang memungkinkan terutama bagi masyarakat yang rumahnya sulit dijangkau oleh armada persampahan maka dapat melakukan pengolahan sampah organik menjadi kompos dengan metode Takakura composting method. Metode pengomposan Takakura ini sebagaimana dikembangkan di Surabaya bekerja sama dengan Kitakyushu International Techno-cooperative Association (KITA). Metode pengomposan tersebut sangat efektif untuk mengolah sisa makanan di rumah tangga.Setelah dikomposkan, maka kompos dapat dimanfaatkan sendiri untuk bertanam baik untuk taman maupun untuk tanaman yang menghasilkan kebutuhan sehari-hari atau yang disebut urban farming, misalnya tomat, cabe, sayuran, dan lain-lain. Bila ini dikembangkan maka akan meningkatkan daya tahan ekonomi masyarakat terutama untuk memenuhi kebutuhan dapur di rumah tangga yang saat ini makin sering terjadi gejolak harga untuk komoditas pertanian tertentu.

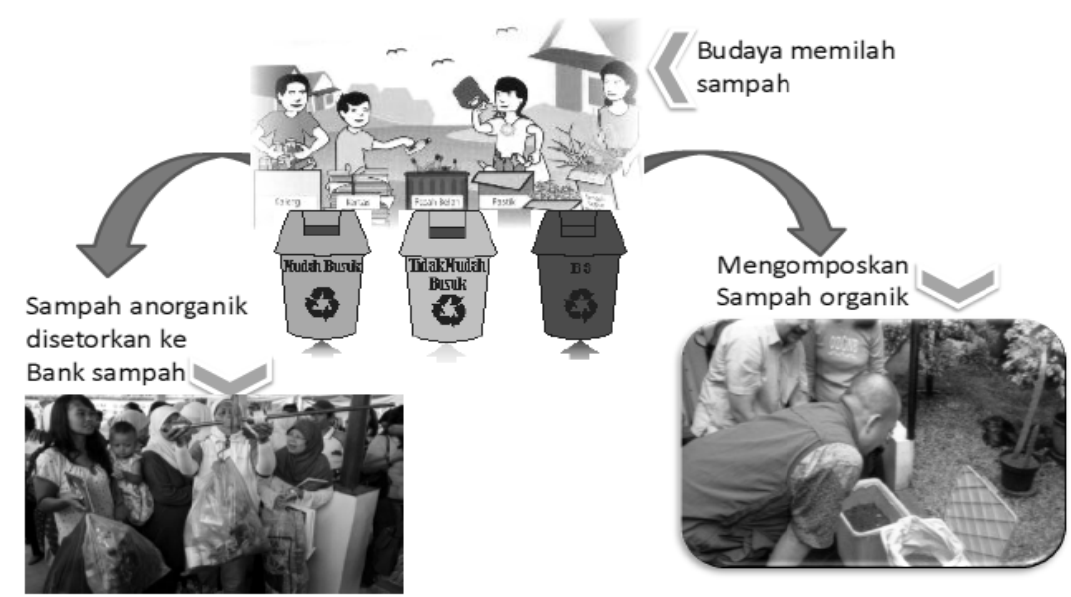

Gambar 3.

Treatment Sampah di Sumber 
Untuk sampah kering/ tidak mudah busuk/ anorganik yang merupakan bahan baku daur ulang seperti plastik, botol, kertas, logam, kertas duplex, karton, dan lain-lain masyarakat dapat ditabungkan ke bank sampah atau koperasi sampah. Layaknya sebagai sebuah bank, dalam bank sampah yang biasanya skala RW, warga masyarakat adalah sebagai nasabah dan menyetorkan jenis sampah tertentu ke bank sampah tersebut. Setelah dikonversi dengan nilai uang, para nasabah dapat menyimpan uang tersebut sebagai tabungan untuk diambil sewaktu-waktu.

\section{b. Treatment di skala kawasan}

Slala kawasan dapat didefinisikan skala RW, skala kelurahan, atau tidak ditentukan berdasarkan batas administratif tergantung jangkauan pelayanannya. Terdapat tiga kemungkinan bentuk model pengolahan dan pemanfaatan sampah bernilai ekonomi dalam skala kawasan, yaitu: bank sampah, tempat pengelolaan sampah terpadu (TPST) 3R, bisnis menengah (intermediate business) bank sampah, dan supermaket sampah.

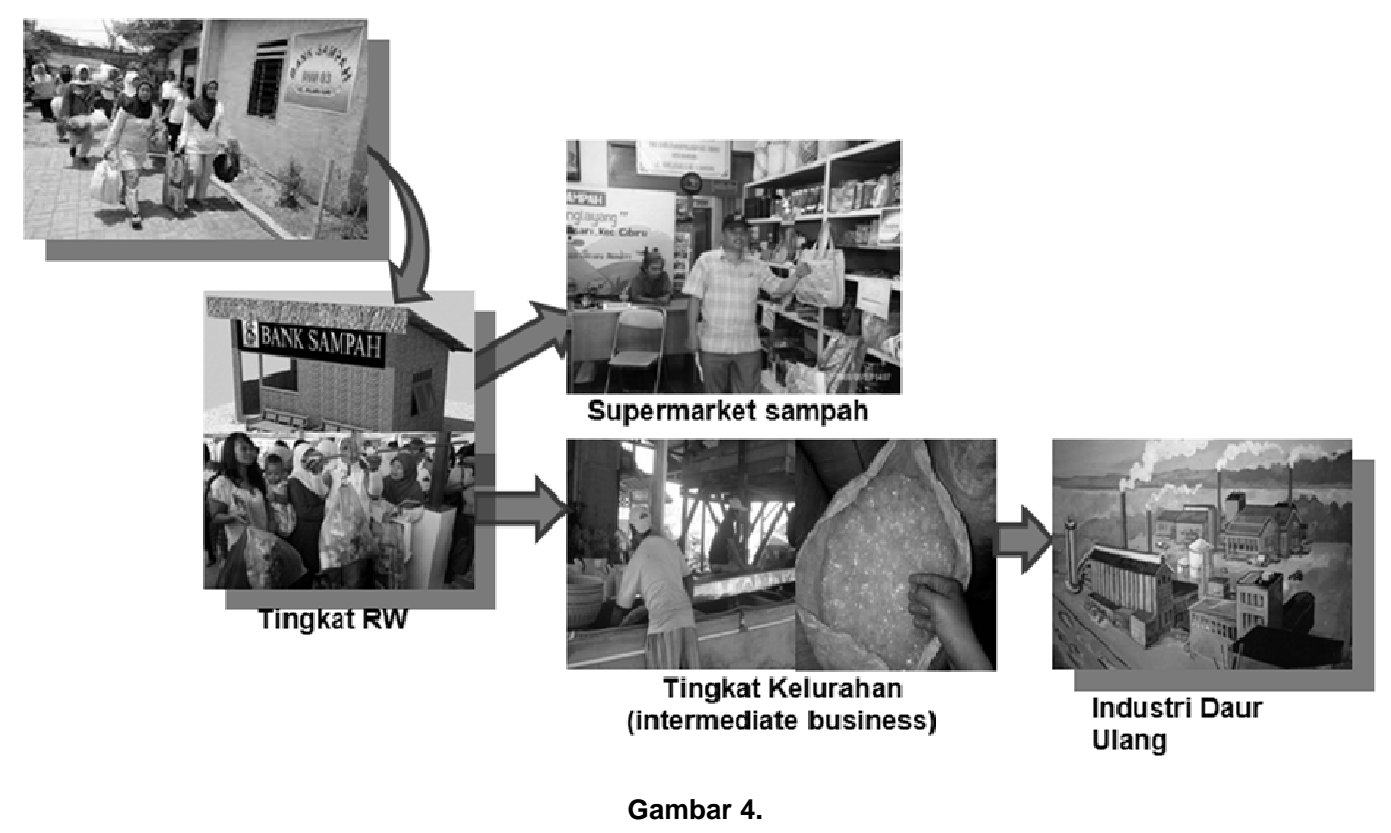

Jaringan Bisnis Bank Sampah Skala Kawasan dan Kota

Bank sampah adalah sebuah inovasi di masyarakat yang memanfaatkan nilai ekonomi dari sampah. Konsep bank sampah lahir di sebuah daerah di Jogjakarta dimana masyarakat mengumpulkan dan menyetorkan jenis sampah tertentu yang umumnya sampah 
kering/ anorganik/ bahan daur ulang ke sebuah bank sampah, kemudian bank sampah menjualnya kembali ke bandar/ lapak. Secara definisi, sebagaimana tertuang dalam Peraturan Menteri Negara Lingkungan Hidup No. 13 tahun 2012 tentang Pedoman Pelaksanaan Reduce, Reuse, dan Recycle melalui Bank Sampah, disebutkan bahwa Bank Sampah adalah tempat pemilahan dan pengumpulan sampah yang dapat didaur ulang dan/ atau diguna ulang yang memiliki nilai ekonomi. Pola pengelolaan usaha bank sampah bisa juga dengan pola koperasi yang menyalurkan pinjaman dengan pembayaran berupa sampah, atau model asuransi baik asuransi kesehatan maupun asuransi pendidikan. Menurut penelitian Permatasari dan Damanhuri (2012 [19]) sistem pengelolaan sampah dengan metode bank sampah dapat diterima dengan baik oleh masyarakat terutama di RW Kelurahan Tamansari dan dapat mereduksi sampah sebesar 0,2417 kg/orang/hari.

Karena bank sampah ini adalah sebuah inovasi untuk menahan sampah bernilai ekonomis untuk tidak dibuang akan tetapi dikumpulkan untuk kemudian dijual ke industri daur ulang maka pengelolaannya memadukan dua motivasi yaitu motivasi lingkungan dan motivasi ekonomi. Oleh karena itu para pelaku umumnya adalah para relawan yang biasanya rentan untuk melakukannya dalam jangka panjang, untuk itu maka perlu dipikirkan bagaimana pengelolaan sampah yang berkelanjutan. Salah satu praktek terbaik yang dapat dilakukan oleh bank sampah yang sudah mengarah kepada keberlanjutan adalah menciptakan sistem pengukuran yang koheren dan pemberian penghargaan kepada mentor, penggurus dan pengepul yang dapat membimbing dan memotivasi perilaku seluruh anggota dari bank sampah. Pihak pengelola juga mampu menjaring kerjasama secara positip dengan pihak Pemerintah dan Lembaga lainnya dalam mencapai sasaran dari keberlanjutan.

Bila bank sampah hanya mengumpulkan jenis sampah anorganik/sampah kering/bahan daur ulang, maka TPST 3R umumnya mengelola dan bahkan mengolah semua jenis sampah, kecuali B3. Secara kelembagaan, TPST 3R umumnya dikelola oleh kelompok swadaya masyarakat (KSM) yang dibentuk berdasarkan musyawarah masyarakat setempat. Petugas pengumpul mengumpulkan sampah dari setiap sumber sampah dengan menggunakan gerobak motor maupun manual ke lokasi pengolahan yang disebut TPST 3R. Di lokasi tersebut sampah dipilah kembali kemudian sampah organik dicacah dan diolah jadi 
kompos dengan metode open windrow. Opsi lain dari pengolahan sampah organik adalah diolah secara anaerob untuk menghasilkan biogas. TPST $3 R$ juga dapat menampung penjualan jenis sampah anorganik dari bank sampah, yang kemudian untuk jenis plastik dicuci serta dicacah serta diklasifikasikan berdasarkan jenis sampah yang lebih spesifik, untuk kemudian dijual ke industri daur ulang.

Kegiatan Supermaket sampah merupakan istilah baru dalam sistem pengelolaan sampah. Supermaket sampah adalah sebuah tempat yang menjadi display dan tempat penjualan bagi produk-produk hasil daur ulang sampah yang dilakukan oleh para pengelola bank sampah. Selama ini banyak bank sampah yang mendaur ulang sampah kemasan menjadi produk-produk yang bernilai ekonomi akan tetapi seringkali mengalami kendala dalam hal pemasaran. Supermaket sampah dapat dijadikan sebagai mediator pertemuan antara produsen produk daur ulang dengan konsumen atau pasar. Keberadaan supermaket sampah ini tidak hanya menjadi mediator antara produsen kerajinan berbahan sampah dengan konsumen akan tetapi juga sebagai mediator antara mereka (produsen kerajinan) dengan para produsen produk sebagai penghasil sampah kemasan yang telah diolah menjadi kerajinan tersebut.
Sebagaimana tertuang dalam UU No. 18 tahun 2008 Pasal 15 bahwa "produsen wajib mengelola kemasan dan/ atau barang yangdiproduksinya yang tidak dapat atau sulit terurai oleh proses alam", yang kemudian dikenal dengan konsep EPR (externded producer responsibilites). Dalam hal ini maka pemerintah Kota Bandung dapat mengembangkan konsep pengelolaan dana CSR (corporate social responsibility) sebagai bentuk insentif bagi pera pengrajin yang telah mengolah sampah kemasan menjadi produk yang seharusnya menjadi tanggung jawab produsen utamanya. Peran pemerintah ini juga dilandaskan pada UU No 18 tahun 2008 Pasal 20 ayat (2) huruf e, dimana pemerintah wajib memfasilitasi pemasaran produk-produk daur ulang.
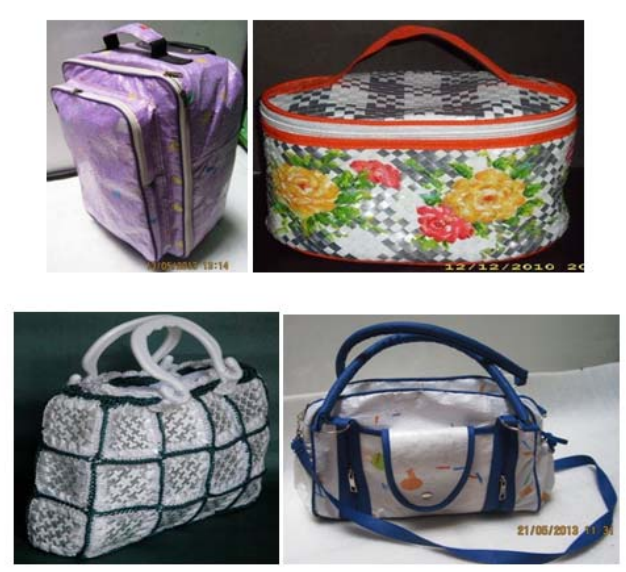

Gambar 5.

Berbagai Produk Kerajinan Berbahan Sampah Kemasan 


\section{c. Treatment di skala kota (hilir)}

Produk yang dihasilkan dari para pengelola sampah dalam skala kawasan baik bank sampah maupun TPST 3R umumnya berupa kompos (untuk sampah organik) dan bahan baku daur ulang. Pada tingkat kota harus menyiapkan unit-unit pengolah hingga menjadi produk akhir yang lebih memiliki nilai jual. Sebagai contoh misalnya untuk produk kompos saat ini para produsen kompos sering menghadapi kendala dalam pemasaran karena kompos sering dikategorikan sebagai non comercial product. Untuk itu maka kompos perlu dimanfaatkan dalam skala kota baik untuk kebutuhan taman kota maupun untuk pertanian. Untuk itu maka diperlukan kerja sama antara para produsen kompos dengan para pengelola taman dan pertanian yang difasilitasi oleh pemerintah kota yang dalam hal ini Kota Bandung. Hal ini berlandaskan pada UU No. 18 tahun 2008 Pasal 20 ayat 2 huruf (e) bahwa pemerintah dan pemerintah daerah wajib memfasilitasi produk daur ulang.

Inovasi dalam kegiatan daur ulang sampah terus berkembang seiring perkembangan ilmu pengetahuan dan teknologi. Khusus untuk sampah organik sisa makanan selain dapat diolah menjadi plastik, inovai lainnya adalah daur ulang sampah sisa makanan menjadi pakan ternak. Hal ini sebagaimana penelitian yang dilakukan Kato, Takaaki; at.al (2012 [20]), yaitu memanfaatkan sisa makanan untuk peternakan di Da Naang Citty, Vietnam. Dari hasil penelitian yang dilakukan bahwa peternakan yang menggunakan pakan sisa makanan nilai gizinya lebih baik, dengan demikian sebagian besar peternak akan meneruskan pemanfaatan sisa makanan untuk peternakan babi tersebut.

Bila sampah organik selama ini banyak orang mengenal diolah menjadi kompos maka di Jepang sebuah penelitian menunjukkan bahwa sampah organik terutama sisa makanan (food waste) dapat didaur ulang menjadi plastik yang mudah terurai (biodegradable plastic), yaitu high-quality polyL-lactate (PLLA). Dalam penelitian yang dilakukan Sakai (2004 [21]) di Kitakyushu Jepang bahwa sampah makanan sangat potensial dijadikan plastik biodegradable tersebut. Hasil penelitian tersebut menunjukkan bahwa plastik yang diolah dari sampah sisa makanan tersebut berkualitas baik. Hal ini merupakan alternatif daur ulang yang dapat dikembangkan dengan resiko lingkungan yang paling minimal. Potensi ini tidak hanya dapat dikembangkan untuk pengolahan sampah makanan di perkotaan akan tetapi juga dapat diimplementasikan 
untuk pengolahan sampah organik lainnya yang mengandung gula yang dapat difermentasi dan kandungan air yang tinggi seperti limbah pertanian [21].

Sementara itu pengolahan sampah di tingkat hilir untuk jenis sampah anorganik dan sampah bahan daur ulang, seperti logam, plastik, kertas, karet, kain, dan lain-lain, saat ini sebenarnya telah berjalan dalam sektor usaha informal. Akan tetapi aktifitas dan keberadaan mereka umumnya hanya terdorong oleh kebutuhan ekonomi bukan dalam rangka pengurangan sampah. Karena hanya motivasi ekonomi maka mereka hanya mengambil dan mengolah sampah yang bernilai ekonomi, dapat didaur ulang, dan produk daur ulangnya mudah dijual. Oleh karena itu kegiatan yang mereka lakukan tidak bisa dijadikan sebagai sebuah kinerja pengurangan sampah karena pemerintah tidak memiliki perhatian khusus. Potensi ini sebenarnya dapat diintegrasikan dalam manajemen sampah kota sebagai upaya pengurangan sampah. Bila potensi usaha sektor informal ini berada dalam "kendali" pemerintah maka para pelaku daur ulang dapat melakukan diversifikasi produk daur ulang yang diintegrasikan dengan kebutuhan pemerintah itu sendiri. Sebagi contoh misalnya ketika plastik kresek atau plastik "daun" yang saat ini makin mendominasi sampah kota maka di tingkat hilir sampah plastik tersebut dapat diolah menjadi wadah-wadah sampah yang dibutuhkan pemerintah kota itu sendiri. Bila di tingkat hilir dibutuhkan bahan plastik bekas maka otomatis hal ini akan berpengaruh pada jaringan pengepul dan bank sampah yang salama ini menganggap kresek tidak laku dijual.

\section{d. Treatment sampah B3 (bahan berbahaya dan beracun)}

Di antara jenis sampah yang dihasilkan dari rumah tangga, terdapat jenis sampah B3 yang dalam UU 18 tahun 2008 dikategorikan sebagai sampah spesifik. Pada Pasal 1 ayat 2 disebutkan bahwa "Sampah spesifik adalah sampah yang karena sifat, konsentrasi, dan/ atau volumenya memerlukan pengelolaan khusus". Sampah B3 rumah tangga saat ini makin banyak dihasilkan terutama jenis elektronik (electronic waste/e-waste), karena e-waste termasuk pada golongan B3 (PP 18/1999 jo 85/1999). Pengelolaan sampah B3 adalah tanggung jawab pemerintah oleh karenanya tidak boleh dikelola secara sembarangan oleh karena itu harus berizin dari Kementrian LH. 


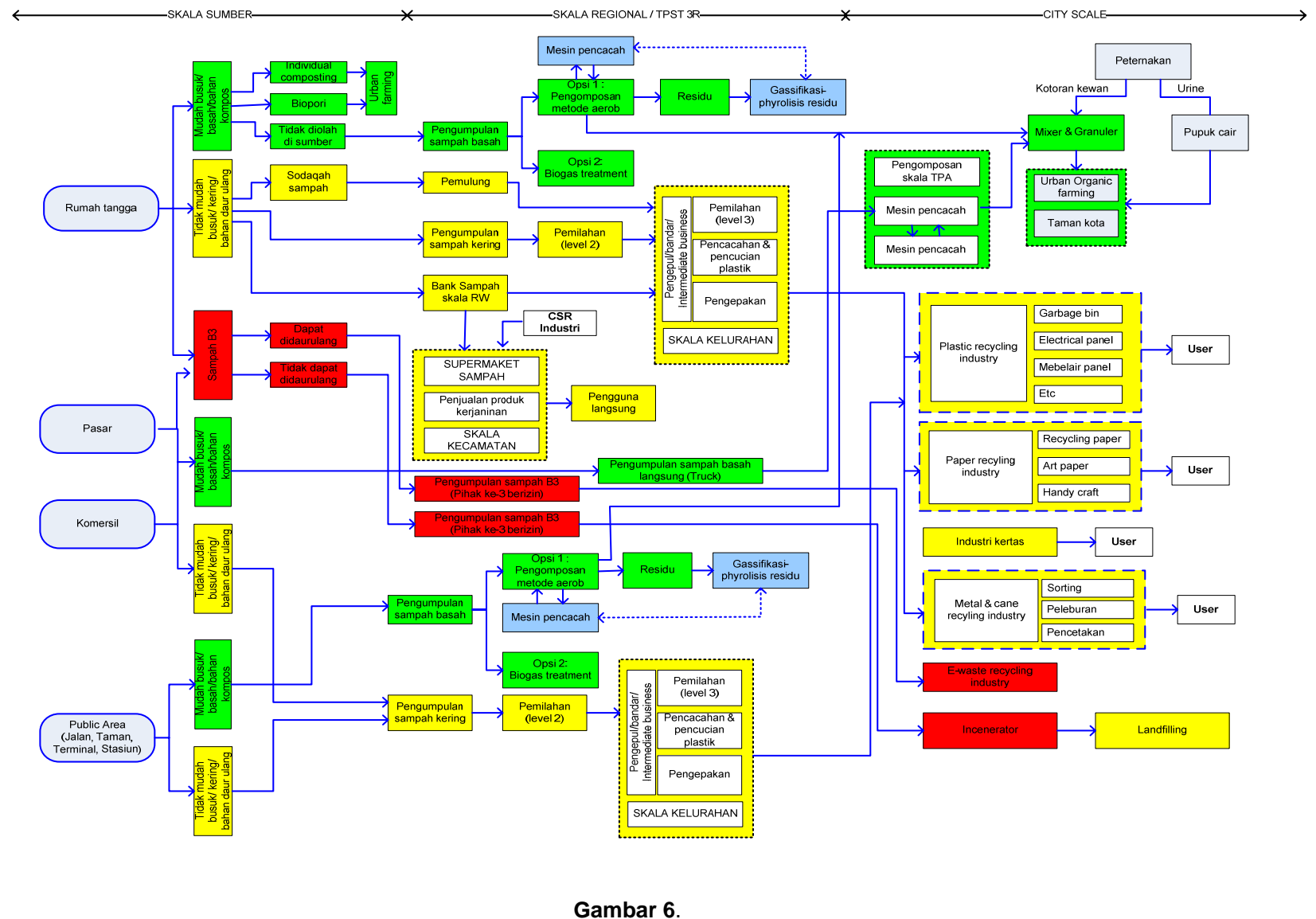

Model Pengelolaan Sampah Terintegrasi.

\section{KESIMPULAN}

Keberadaan Sungai Cikapundung menjadi strategis bagis masyarakat Kota Bandung baik dari segi fungsi sungai tersebut, dan juga merupakan sungai terbesar di Kota Bandung. Namun kini keberadaan sungai tersebut makin tercemar seiring dengan dinamika dan pertumbuhan penduduk. Salah satu masalah yang terkait dengan pencemaran Sungai Cikapundung adalah sampah rumah tangga. Pengelolaan sampah di di DAS Cikapundung menghadapi banyak kendala mulai dari kendala fisiografi, penataan pemukiman yang kurang teratur hingga persoalan manajemen. Untuk itu perlu dicarikan sulusi yang efektif dan efesien dalam pengelolaan sampah di DAS Cikapundung. Sistem 
pengelolaan sampah terintegrasi berbasis ecopreneur merupakan solusi yang ditawarkan, dimana konsep tersebut memadukan 3 komponen yang menjadi unsur penting dalam pembangunan berkelanjutan, yaitu: lingkungan, ekonomi dan sosial. Konsep ini selain dapat menyelesaikan masalah sampah di satu sisi dan juga dapat menjadi peluang ekonomi bagi masyarakat di sisi lain. Akan tetapi keberhasilan sistem tersebut juga tergantung pada pengambil keputusan di tingkat Pemerintah Kota Bandung. Bila sistem ini diintegrasikan dengan sistem manajemen sampah Kota Bandung maka biaya pengelolaan sampah lebih murah dan lebih efesien.

\section{DAFTAR PUSTAKA}

[1] Suganda, E, Yatmo, Y.A., Atmodiwirjo, P. 2009. Pengelolaan Lingkungan dan Kondisi MasyarakatPada Wilayah Hilir Sungai.Makara, Sosial Humaniora, Vol. 13, No. 2, Desember 2009: 143-153

[2] Clark, N. 1966. Evolutionary dynamics andsustainable development: A system approach. Cambridge: Cambridge University Press.

[3] Yustiani, Y.M., Lidya, L. 2016. Towards an Information System of Modeling and
Monitoring of Cikapundung River, Bandung, Indonesia. Procedia Engineering 154, 353-360

[4] BPLH Kota Bandung dalam http://www.citarum.org/node/1174, diakses pada 28/04/2014, 11:16

[5] Yustiani, Y.M., Komariah, I. 2017. Investigation on the Biodegradation Capacity of Urban Rivers in Jakarta, Indonesia. International Journal of Geomate Vol 12 Issue 34, 45-50

[6] Waspola-Gemricik.2013. Laporan Base Line Survey Sungai Cikapundung. Waspola Facilities, Jakarta

[7] Zaman, A. U. 2010. Comparative study of municipal solid waste treatment technologies using life cycle assessment method. Int. J.Environ. Sci. Tech., 7 (2), 225-234.

[8] Tchobanoglous, George; Kreith, Frank. 2002. Handbook of Solid Waste Management Second Edition., McGrawHill, New York.

[9] Joe E. Heimlich, Kerry L. Hughes, Ann D. Christy. Integrated Solid Waste Management.

http://ohioline.osu.edu/cdfact/pdf/0106.pdf, diakses pada tanggal 01/04/2014 pukul 22.03 
[10] Nowosielski, R.A; Kania, M. Spilka. (2008). Integrated recycling technologyas a candidate for best available techniques. International Scientific Journal, published monthly by the World Academy of Materialsand Manufacturing Engineering.

[11] Guerrero, Lilliana Abarca; Maas, Ger; Hogland, William; 2013. Solid waste management challenges for cities in developing countries.journal homepage: www.elsevier.com/locate/wasman

[12] Surjandari, Isti; Akhmad Hidayatno, Ade Supriatna. (2009). Model Dinamis Pengelolaan Sampah untuk Mengurangi Beban Penumpukan. Jurnal Teknik Industri, Vol. 11, No. 2, Desember 2009, pp. 134-147ISSN 1411-2485. Fakultas Teknik, Departemen Teknik Industri, Universitas Indonesia Kampus UI Depok, Jakarta 16424.

[13] Prawiradinata, Rudy S. 2004. Integrated Solid Waste Management Model:The Case of Central Ohio District. Dissertation. The Degree Doctor of Philosophy in the GraduateSchool of The Ohio State University

[14] Chang, Ni Bin; Shoemaker, Christine A.; and Schuler, Richard E.; 1996. Solid WasteManagement System Analysis with Air Pollution and Leachate Impact Limitation.Waste management \& Research, 1996, 14, pp.463-481

[15] Salim, E. (1993). Pembangunan berwawasan lingkungan. LP3ES, Jakarta

[16] Becker, E. (1997). Sustainability: A cross-disciplinaryconcept for social transformations, management ofsocial transformation (MOST). UNESCO Policy Papers 6. Paris: UNESCO.

[17] Taiwo, Oluwatoyin; Otieno, Fred; Vorster, Kobus; Fowler, Marie. 2009. lintegrated solid waste management: an innovative and pragmatic approach to solving dwindling landfill capacity in Johanesburg.

Source:http://www.saice.org.za/downloa ds/monthly_publications/2009/2009-

Civil\%20Aug/\#/0

[18] Chang, N. B., \& Lin, Y. T. (1997). An analysis of recycling impacts on solid waste generation by time seriesintervention modeling. Resources, Conservation and Recycling, 35(3), 201-

214.http://dx.doi.org/10.1108/17506180 810891582

[19] Damanhuri, Enri; Padmi, Tri (2010).Pengelolaan Sampah, Diktat 
Infomatek Volume 20 Nomor 1 Juni 2018 : 9 -26

Kuliah TL-3104. Program Studi Teknik Lingkungan, ITB.

[20] Kato, T., Pham, D.T.X, Hoang, H.; Xue, Y., Tran, Q.V. (2012). Food residue recycling by swine breeders in a developing economy: A case studyin $\mathrm{Da}$ Nang, Viet Nam. journal homepage: www.els evier.com /locate/wasman
[21] Sakai, Kenji; Taniguchi, Masayuki; Miura, Shigenobu; Ohara, Hitomi; Matsumoto, Toru; and Shirai, Yoshihito; (2004). Making Plastics from GarbageA Novel Process for Poly-LLactateProduction from Municipal Food Waste. Journal of Industrial Ecology, Volume 7 No. 3-4 